\title{
The Importance of Pedestrianization in Cities- Assessment of Pedestrianized Streets in Nicosia Walled City
}

\author{
By Kozan Uzunoğlu ${ }^{1}$, Semra Sema Uzunoğlu²
}

\begin{abstract}
Especially in the old historical cities, creating traffic-free areas/streets has become an important approach in recent years. One of these cities which is the last divided capital city and one of the most important cultural heritages of the Mediterranean region in the island of Cyprus is the Nicosia Walled City. Within this study, the existing situation of pedestrianized areas in the Walled City in north Nicosia were examined. In literature review part, the importance of pedestrianization, reasons and benefits of pedestrianization, examples of pedestrianized areas/streets around the world are reviewed. The pedestrianized streets/areas in the north Nicosia Walled City were examined on-site, photographed, their current status was revealed and evaluated according to determined criteria. Each street/area was evaluated in terms of functions in the street, mobility, accessibility by car or public transportation, social/community activities, economic development and quality of physical environment. When the old city of Nicosia is analyzed in the context of these criteria, it has been observed that the pedestrianized areas have an increasing social, cultural and economical contribution to the city. In addition to its historical features, the places and activities that attract the people especially young population and tourists, bring life to this region. In terms of environmental aspects, visual incompatibilities were observed even in the streets where pedestrianization studies have been carried out recently. There are also problems about vehicle and pedestrian traffic that affect users. The study was completed by making suggestions at the end of the study.
\end{abstract}

Keywords: pedestrianized streets, pedestrianized squares, Nicosia Walled City, Cyprus

\section{Introduction}

Cities grow over time and tends to develop in a contemporary sense. Central and/or local governments direct the investments of the people living in the city with the planning policies they produce. Accordingly, certain points of the city complete their development in a good or bad way. At this point, the regions that have completed their construction in the city to a large extent need to be overhauled in accordance with the conditions of the day in order to survive in a modern sense. Of course, such a regional planning works should be the responsibility of local governments.

As cities grow, certain areas are formed as attraction points. While the density increases at these areas, they cannot fully perform their functions due to the density. At this point, if the necessary intervention is not made, these parts of the city may become uninhabitable after a while. This intervention should be carried out in such a way that

|1Assistant Proffessor Dr., Bahçeşehir Cyprus University, Faculty of Architecture and Engineering, Department of Architecture.

${ }^{2}$ Assistant Proffessor Dr., Bahçeşehir Cyprus University, Faculty of Architecture and Engineering, Department of Architecture. 
certain regions of the city can be transformed to pedestrianized areas, taking into account the current situation and urban problems to be solved regarding public interest.

Pedestrian streets generally have facilities for relaxing, entertaining among other activities. Landscape elements can be provided like trees and other vegetation. Water elements like pool fountains can be attractive and focus of activities. Street lighting and furnitures are also essential elements of pedestrianized streets. Such streets are streets designed to allow people to socialize, to walk safely. These streets should also be accessible to everyone.

Especially in the old historical cities, creating traffic-free areas/streets has become an important approach in recent years. One of these cities is the Nicosia Walled City which is the last divided capital city and one of the most important cultural heritages of the Mediterranean region, located on the island of Cyprus. Within this study, the pedestrianized areas in the Walled City in North Nicosia will be examined. Following the literature review about pedestrianization, reasons and benefits of pedestrianization, examples of pedestrianized areas/streets around the world will be reviewed. Then research methodology will be explained and results will be discussed. At the end of the study, recommendations will be made regarding the results.

\section{Pedestrianization in Cities-Reasons-Benefits}

Brambilla \& Longo (2003) described pedestrian districts as a portion of the city where vehicular traffic is eliminated. This type of traffic-free zoning suits the physical conditions of historic central areas and has been adopted by many European cities. "Pedestrian streets", on the other hand, are the streets where traffic is not allowed, except emergency vehicles, service and delivery trucks which are often allowed during restricted hours. The "pedestrian street" term is used as synonymous of "pedestrian mall," which is first used in North America as a term describing traffic-free zones.

Soni \& Soni (2006) emphasized the rapid growth of transportation related problems like traffic congestion, accidents and injuries, pollution, noise etc. because of the the rapid increase in numbers of private vehicles in centers of the cities and old towns. They also indicated that the pedestrians are affected in a bad way. Such areas become places degraded to the extent that people do not want to visit anymore. As a solution and a most feasible way for upgrading mobility and environment, they suggest pedestrianization of these areas which they think a very effective, lowcost and sustainable solution.

In the publication by The Active Living Resource Center-European Commission (2004) has published a handbook explaining the ways for planning public spaces to eliminate vehicular traffic for pedestrian's free movement and new ways to create attractive and popular public areas in Europe. In handbook, the problems associated with increasing traffic and congestion in terms of environmental, social and economic costs for urban communities are illustrated in Figure 1. 


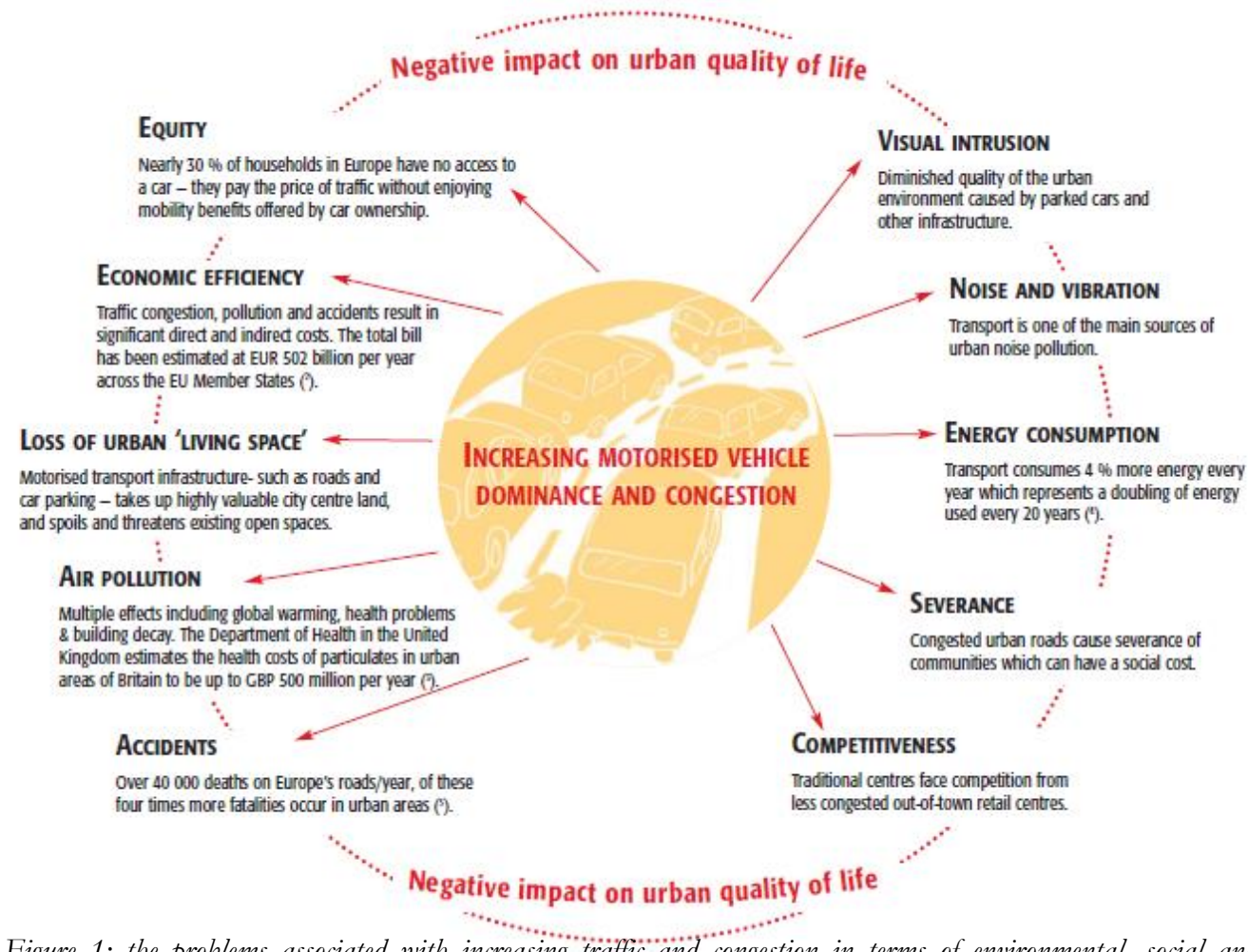

Figure 1: the problems associated with increasing traffic and congestion in terms of environmental, social and economic costs for urban communities (European Commission 2004)

After identifying the issues, the theory of 'traffic evaporation' is explored as a concept in the handbook. The idea is that, reducing road capacity for cars in congested city centres can represent a sustainable, efficient planning solution. Eight European cities (Kajaani, Finland; Wolverhampton, England; Vauxhall Cross, London, England; Nuremberg, Germany; Strasbourg, France; Gent, Belgium; Cambridge, England; Oxford, Englandare) examined as case studies and at the end of the handbook, guidelines are provided to assist politicians and planners working to develop more sustainable transport strategies for Europe's towns and cities.

Nieuwenhuijsen \& Khreis (2016) described the plans for private car free cities and the effects of this on public health by reviewing the scientific literature. Zainol et al. (2016) made a research regarding the walkability and aimed to assess the physical qualities of pedestrianized areas in Georgetown-Penang which is a UNESCO World Heritage Site by using features related to walkability like pathway, zebra crossing, signage, personal safety, traffic flow and, aesthetics \& amenities. They concluded after the research that if sufficient activities are not provided along the streets, built heritage features and possibility for physical walking does not encourage high walkability. ElFouly \& Gawad Ghaly (2017) made a research, from another perspective, aiming to explore the perceived impact of pedestrianization of a street in a historical town from the local businesses perspectives whithin the Egyptian context. Parajuli \& Pojani (2017), made personal interviews with local planners in two cities and examined barriers to the pedestrianization of city centres. According to the results of the research, the barriers were revealed as the 
opposition from residents, drivers and local shop owners/merchants, vehicular access for delivery, designing the alternative transport routes and parking problems, cost recovery, enforcement and institutional and political support. Souza \& Mulaski (2018) proposed a project as an innovative approach for solving the urban problems of Curitiba, Capital State of Parana, which is a State in the south of Brazil. Their proposal was a system of integrated walkways- elevated sky walkways, pedestrian walkways, squares, parks, bus stations, offices and malls. They indicated that proposed project will minimize the traffic problems and improve the safety. They also emhasized that revitalization of the commercial area and preservation of the environmental will be possible with their economically feasible project. Yassin (2019), proposed an integrative literature between the pedestrianization and livability. She also analysed the examples of different approaches around the world and introduced an implementation approach to pedestrianization for achieving the objectives like; removing the barriers that might be faced during the implementation, tactics for re-attracting the people to the core of the city again, creating a sustainable environment, etc. Yassin indicated that by renovating the city core, the livability of the whole city could be restored and this causes a sustainable urban development thru the creative tactical urbanism. Brambilla \& Longo (2003), offers guidelines and checklists for design of pedestrianized streets, created as traffic-free zones. Researchers explained the benefits of traffic free zones (Table 1).

Table 1. The benefits of traffic free zones (Brambilla \& Longo, 2003)

\begin{tabular}{|c|c|}
\hline $\begin{array}{l}\text { Attracting more people to } \\
\text { the area }\end{array}$ & $\begin{array}{l}\text { This creates opportunities for socializing, shopping, having fun, } \\
\text { do business, along with the increasing of financial sources for } \\
\text { both the citizens and municipality. }\end{array}$ \\
\hline Providing a sense of place & $\begin{array}{l}\text { Having the sense of place strengthens community identity and } \\
\text { pride which improves relations in the community. It creates a } \\
\text { place where all people can gather, while reducing feelings of } \\
\text { alienation. }\end{array}$ \\
\hline $\begin{array}{l}\text { Reducing noise and air } \\
\text { pollution. }\end{array}$ & $\begin{array}{l}\text { Traffic free zones will help to reduce noise and air pollution in } \\
\text { the area. }\end{array}$ \\
\hline $\begin{array}{l}\text { Providing a safe, at the same } \\
\text { time attractive environment }\end{array}$ & $\begin{array}{l}\text { A pedestrianized area as a public environment is very important } \\
\text { in the community life and it is accessible to everyone in the } \\
\text { society. }\end{array}$ \\
\hline $\begin{array}{l}\text { Improving the environment } \\
\text { visually }\end{array}$ & $\begin{array}{l}\text { All signs, lights, spaces, colors and textures can be designed for } \\
\text { pedestrians rather than persons in the vehicles. }\end{array}$ \\
\hline $\begin{array}{l}\text { Promoting the urban } \\
\text { conservation }\end{array}$ & $\begin{array}{l}\text { This includes planting and landscaping, cultural conservation } \\
\text { which includes preservation, building restoration and renewal. }\end{array}$ \\
\hline Increase in property values & This results in the city's income from real estate taxes. \\
\hline $\begin{array}{l}\text { Encouraging walking and } \\
\text { providing lanes reserved for } \\
\text { bicycles and public } \\
\text { transportation vehicles. }\end{array}$ & This improves mobility and consequently helps saving energy. \\
\hline $\begin{array}{l}\text { Decrease in the number of } \\
\text { accidents }\end{array}$ & $\begin{array}{l}\text { This helps for saving lives, reducing police work and judicial } \\
\text { time. }\end{array}$ \\
\hline $\begin{array}{l}\text { Promoting } \\
\text { participation }\end{array}$ & $\begin{array}{l}\text { Citizen participation in the planning and implementation phases } \\
\text { of the pedestrianization process. This is an instrument for } \\
\text { education of people and their engagement in urban life. }\end{array}$ \\
\hline
\end{tabular}


Aydın \& Ayataç (2015) made a survey and observation in the pedestrianization project in Eminönü-Hobyar Neighbourhood which is one of the most important historical regions in İstanbul-Turkey. According to Aydın \& Ayataç, the pedestrianized places are used only for transit purposes and they do not have the urban public space characteristics, public interest is disregarded as well. At the end of the study, they emphasized the importance of all participation tools to be used and indicated that the space must appeal to all users.

In Table 2 and 3 the examples of pedestrianized areas/streets around the world can be seen.

Table 2. Pedestrianized street examples around the world

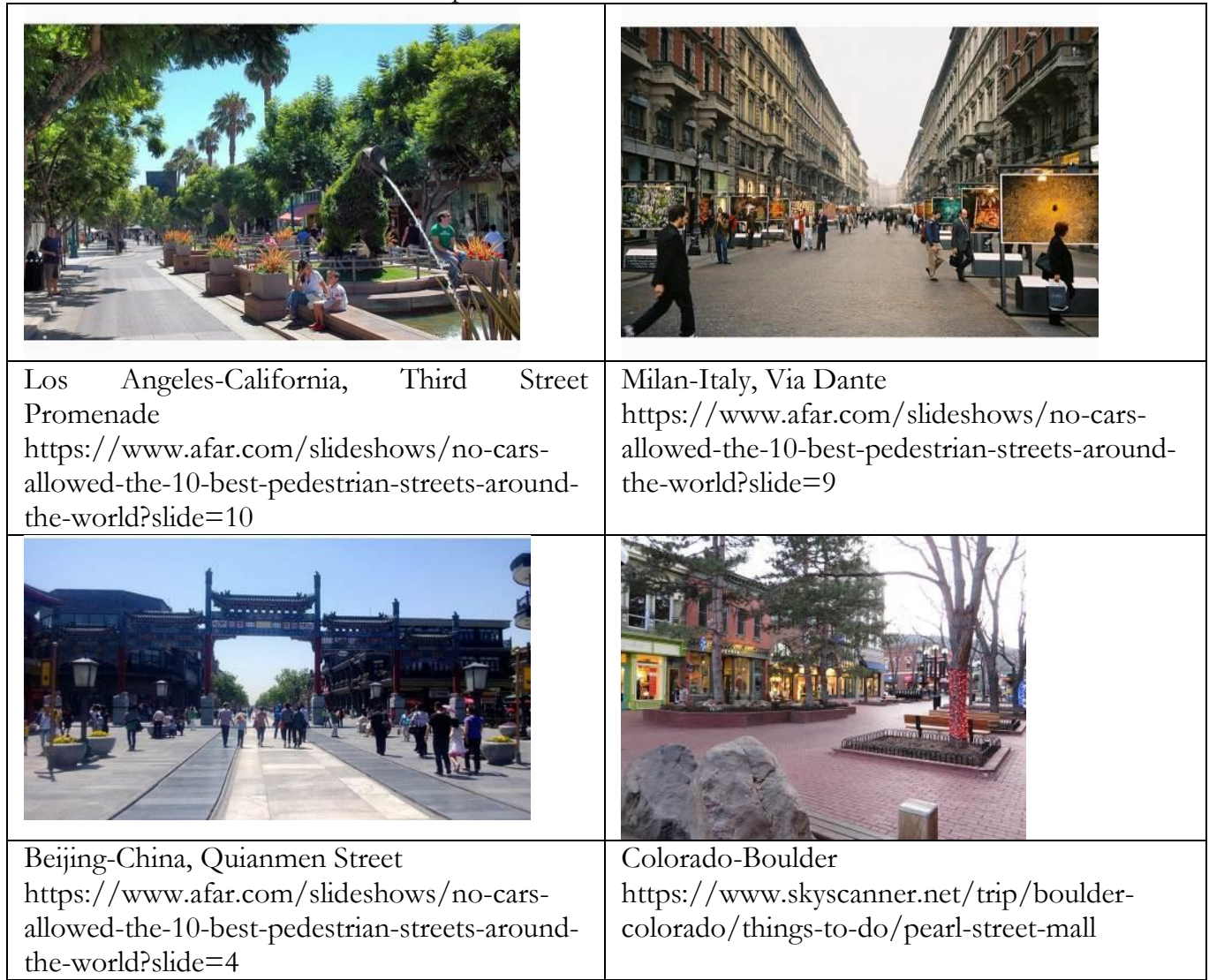




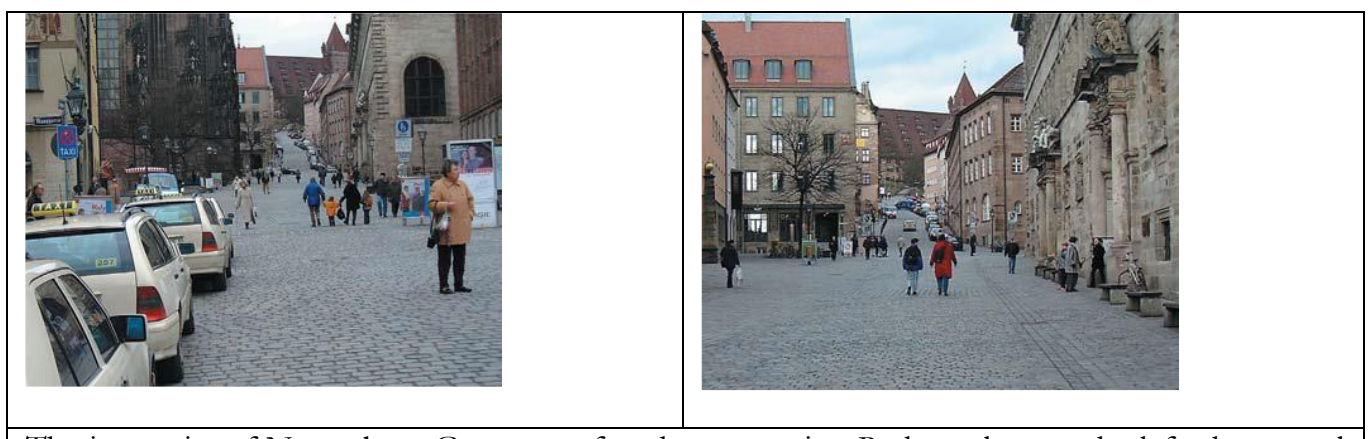

The inner city of Nuremberg-Germany, after the renovation Rathausplatz on the left, the central market square on the right(European Commission,2004)

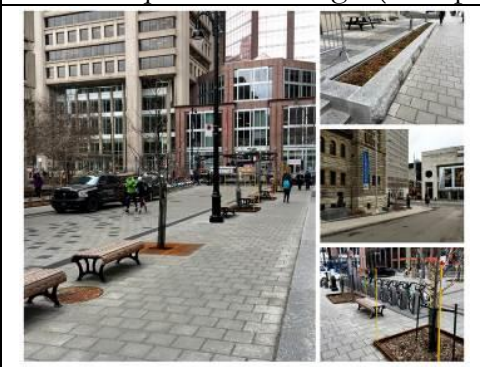

Montreal-The Streetscape at Sherbrooke and McTavish Streets(Gladysz, 2018)

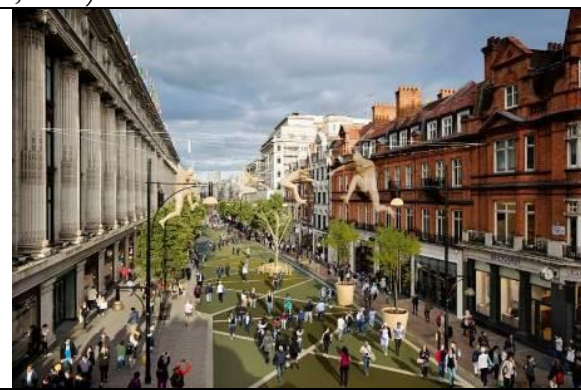

London-Oxford Street (chambers, 2017)

Table 3. Pedestrianized street examples around the world

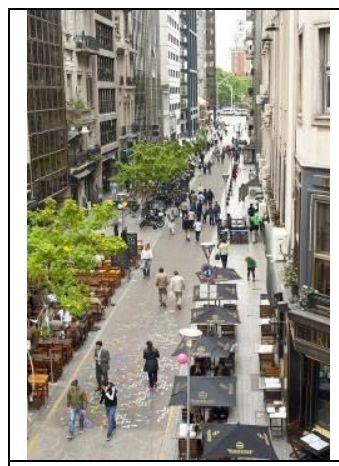

Buenos Aires-A Pedestrian-Scale

Downtown (Valente, 2014)

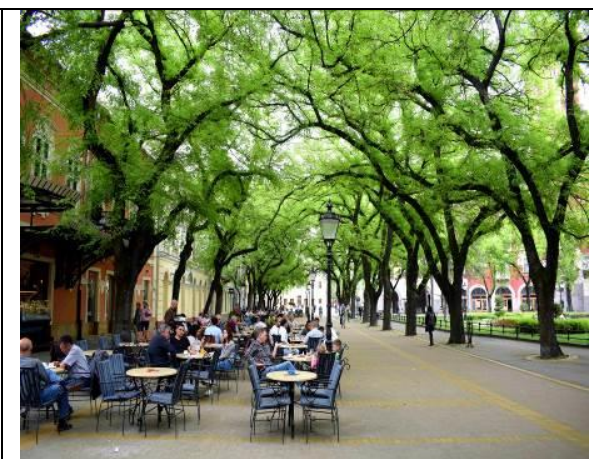

Subotica, Serbia

http://www.slavictravels.com/suboticaserbia/ 


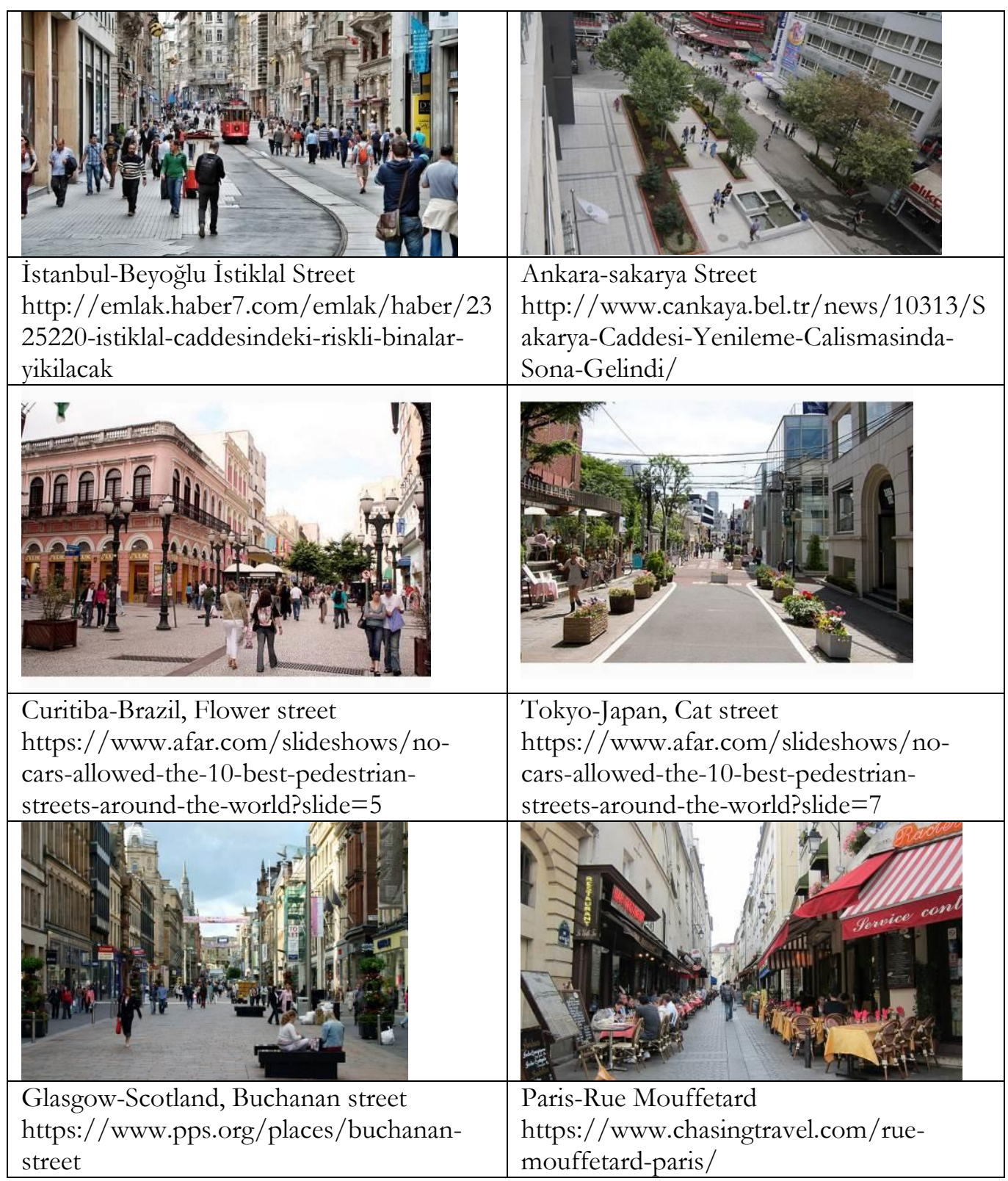

\section{Study Area}

Nicosia is the Capital city located in the Cyprus island (Fig. 2). Cyprus is the third biggest island after Sicily and Sardinia in the Eastern Mediterranean. Cyprus is divided by the green line which is a UN-controlled area since 1974. Today, the city of Nicosia, as a last divided city in the world, maintains its two-zone character. However, it 
is possible to travel between two sides from three crossing points between the Greek side and the Turkish side (Nicosia Turkish Municipality, n.d.)

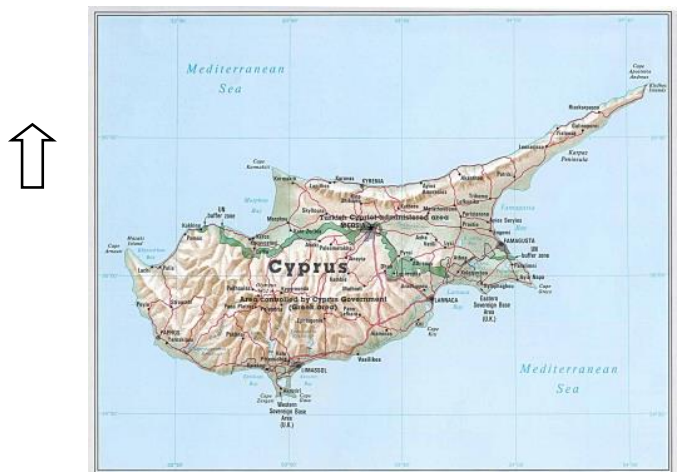

Figure 2: Cyprus map http:// www.orangesmile.com/gezirehberi/kibris/ulke-haritalari.htm

Walled City is one of the most dynamic regions of Nicosia city besides being an historical city and a part of cultural heritage in Cyprus (Fig. 3). In commercial terms, many shops, butiques as well as many restaurants gather in this region. Apart from these, markets, furniture stores, banks, pastry shops, private clinics, offices, real estate agents, residences, boutiq

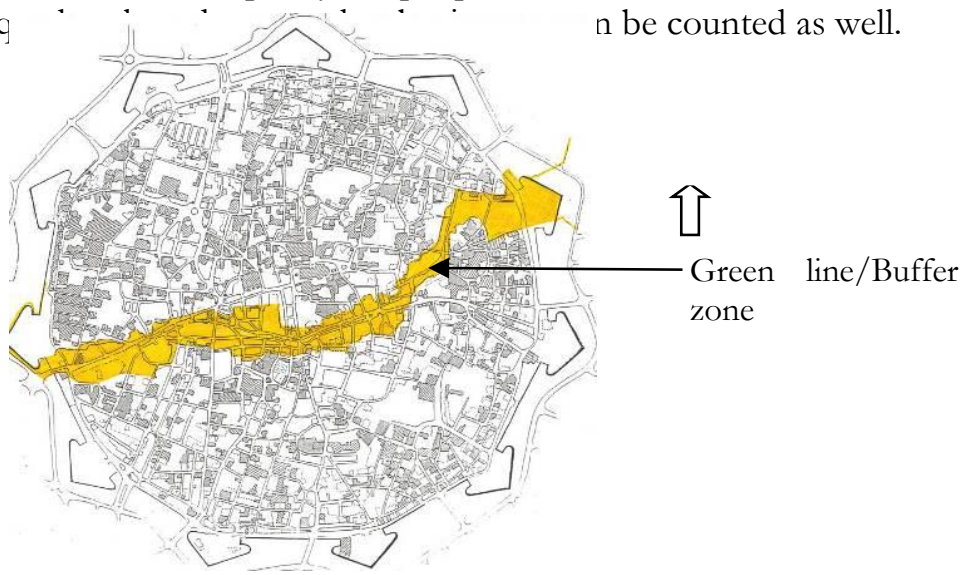

Figure 3: Nicosia Walled City map

http:/ / www.thecypriotpuzzle.org/moving-checkpoints-outside-nicosia-walled-city-for-a-bi-communal-free-zone/

Pedestrianization of certain regions in historical cities is very important for increasing the city's value, sustainability and development in terms of tourism. When the Walled City in Nicosia in Northern Cyprus examined in this sense, it can be said that the pedestrianized areas contributed a lot to the city. Pedestrianization works are carried out by the Turkish Municipality of Nicosia. Pedestrianizaton project by the Turkish Municipality of Nicosia can be seen in Figure 4. 


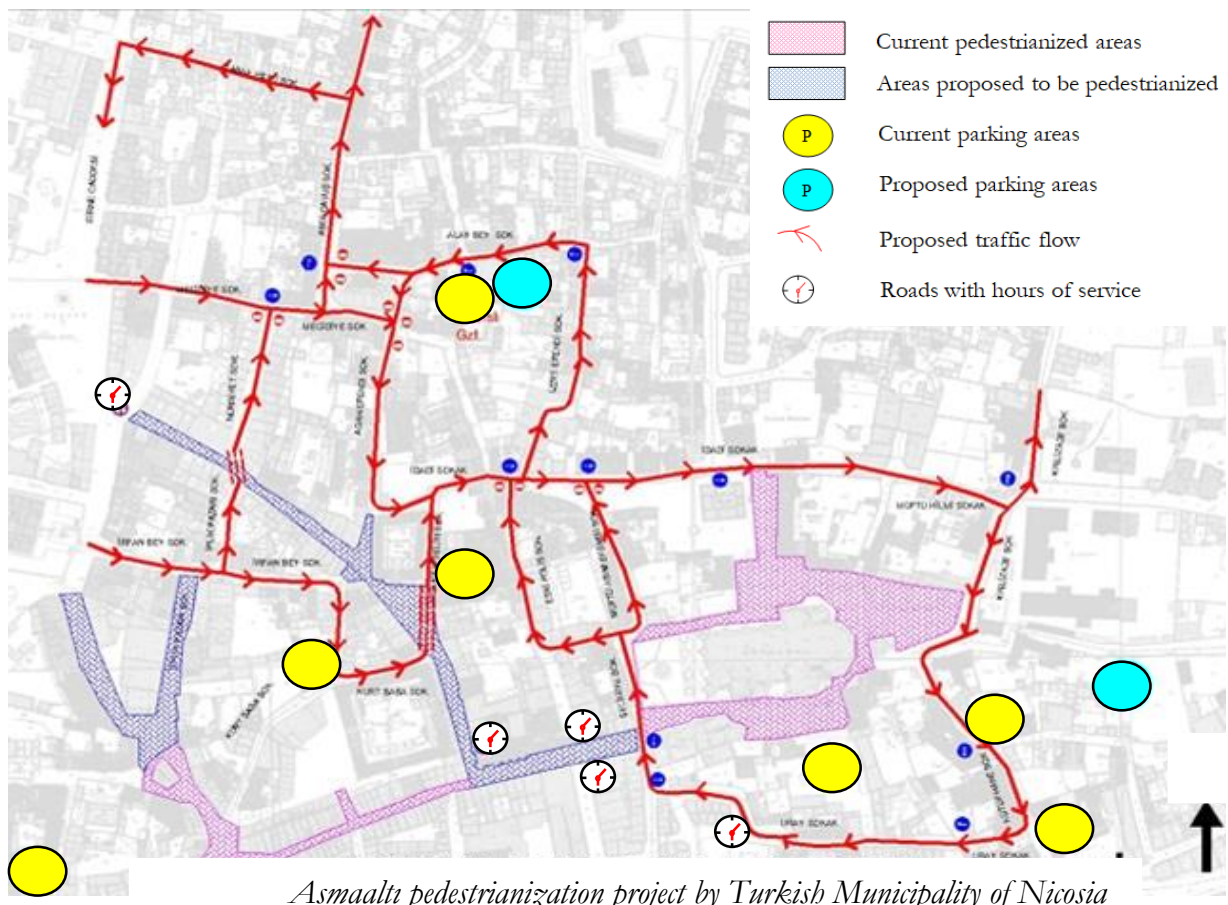

Figure 4: Asmaaltı pedestrianization project

bttps:/ / www.lefkosabelediyesi.org/asmaalt-trafik-ak-s/harital

After the opening of Ledra/Lokmac1 Street crossing which is in two phases, PHASE 1 Safety interventions to guarantee safe pedestrian crossing; April 2008 and PHASE 2 Repairs and consolidation interventions of the buildings along the road of the crossing; 2010-2012, the area became more popular for tourists and local people (Turkish Cypriots and Greek cypriots) as well. Ledra/Lokmac1 Street gate which is located at the centre Nicosia Walled City was opened as the sixth crossing point in the island, to encourage a return to normal civilian and pedestrians' activities along the street (UNDP, 2020). The gate is on the pedestrian shopping axes till the end of Ledras Street in south Nicosia (Fig. $5,6)$.

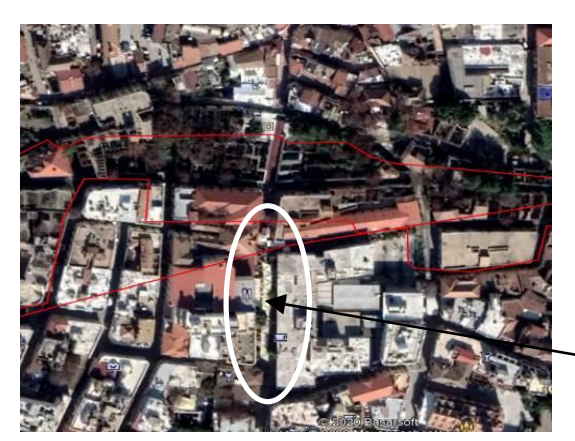

Figure 5: Lokmac gate which providing passage in between the north and the south sides of Nicosia

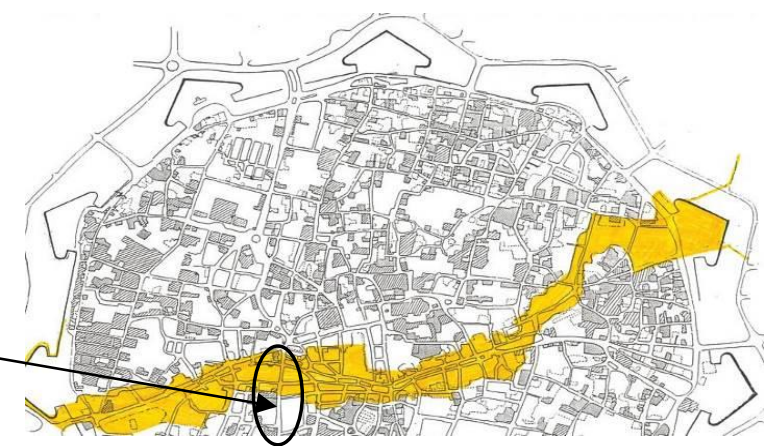

Figure 6: North Nicosia map

http:/ / wmw.thecypriotpuz:le.org/ moving-checkpoints-outsidenicosia-walled-citv-for-a-bi-communal-free-zonel 
In the last two decades, due to the increase in the number of university students in North Cyprus, the increase in commercial ties abroad, the intensive use of restaurants and cafes especially at noon and in the evening has made the region attractive. Some of the buildings in the area have been restored and turned into bars, cafes, library-cafes and restaurants preferred by young people and become places for young people to use. Thus, both young people will have places to spend time and at the same time they can breathe authentic air. It is a good development that the number of such places increases everyday. Various activities are held during the day as well as at night, including concerts, street music and dance performances, bicycle tours and open markets. There are also associations where young people can learn local folk dance and music. The allocation of some buildings to universities, especially in the fields of architecture and art, has been a great opportunity for young people to get educated in such an historical atmosphere and also an opportunity for them to use the city.

\section{Methodology}

In this study, pedestrianized areas in the Walled City of north Nicosia will be examined. Their current status of these areas/streets will be revealed with the help of visuals. Existing situation of the pedestrianized areas/streets are shown in yellow color in Figure 7, together with the historical landmarks in north Nicosia walled City. The criteria in Brambila and Longo's study (2003) "Pedestrian zones: a design guide" was adapted as a guide to be used in evaluating the pedestrian areas in the Walled City. "Functions" includes the use and accessibility of the street and services. "Mobility" as another criterion means the mobility of people, goods, vehicles of service and emergency, access for maintenance of the service system. "Accessibility by car or public transportation" includes, street patterns, bus lines, traffic signs, lighting, parking facilities. Resting and chatting, playing, cultural and educational events are included in "Social/community activities". "Economic development" means income producing functions, office and trade related activities, needs and requirements. As the last criteria, "Quality of physical environment" means preservation of historical assets, green areas, vegetation, fountains and other elements enhancing the visual quality of the streets. In Table 4-12 the evaluation of streets can be seen. 


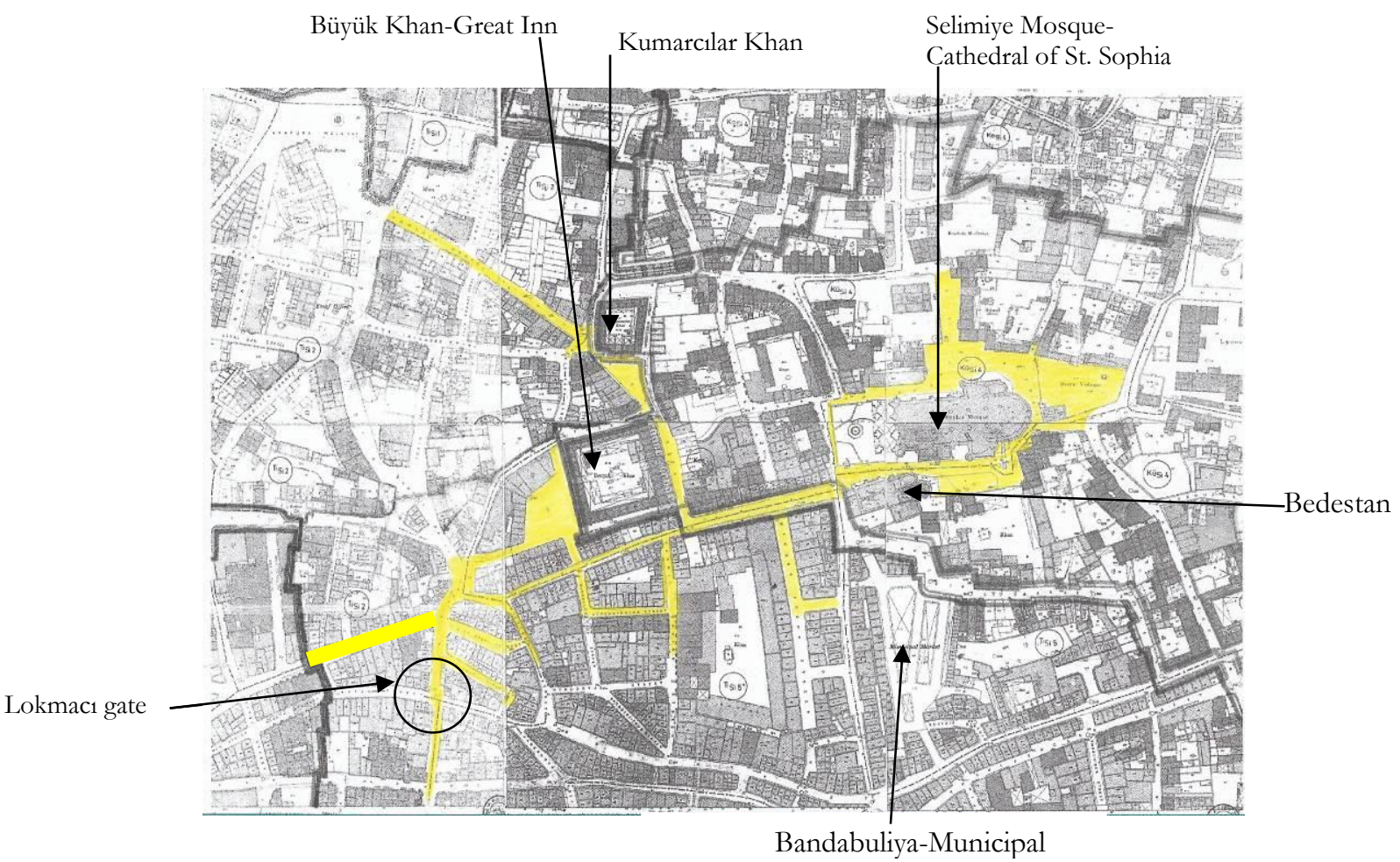

Figure 7: Existing situation of pedestrianized streets/areas in the Walled city-north Nicosia https:/ / spd.gov.ct.tr/LEFKO\%C5\%9EA-\%C4\%BOMAR-PLANI

Table 4: Arasta Street, Mithat Paşa Street, Şehit Eybil H. Çetin Street, Yeşil Gazino Street, Şehit Mustafa Hasan Street, Mithat Paşa St.

\begin{tabular}{|l|l|l|l|}
\hline Functions & $\begin{array}{l}\text { On the street, there are } \\
\text { fabric stores, gift } \\
\text { shops, boutiques, } \\
\text { cafes, restaurants and } \\
\text { small businesses that } \\
\text { produce sell local } \\
\text { sweets. }\end{array}$ \\
\hline Mobility & $\begin{array}{l}\text { At certain times, shops } \\
\text { can get services for } \\
\text { loading and unloading } \\
\text { purposes. With the } \\
\text { permission to be } \\
\text { obtained from the }\end{array}$
\end{tabular}




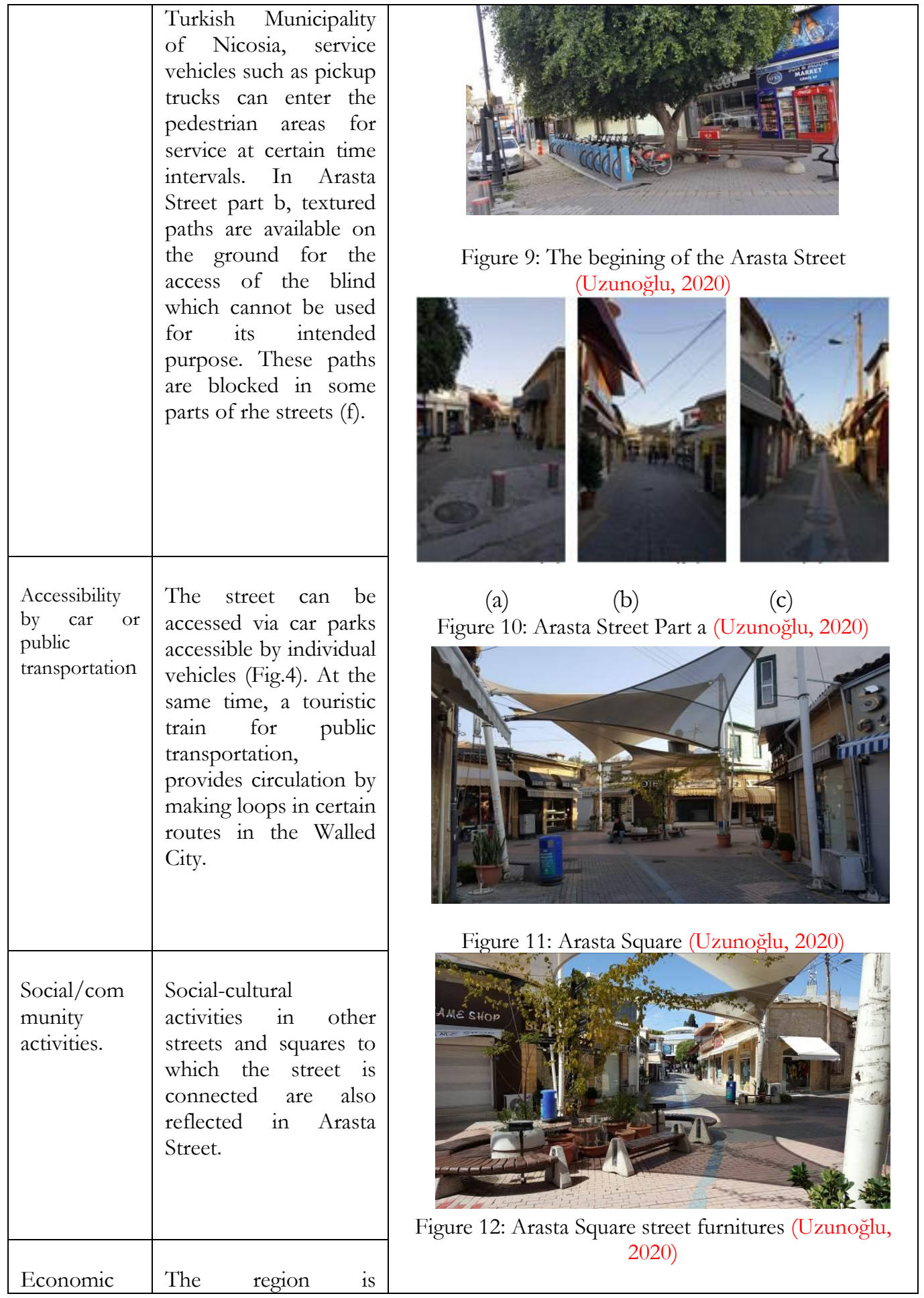




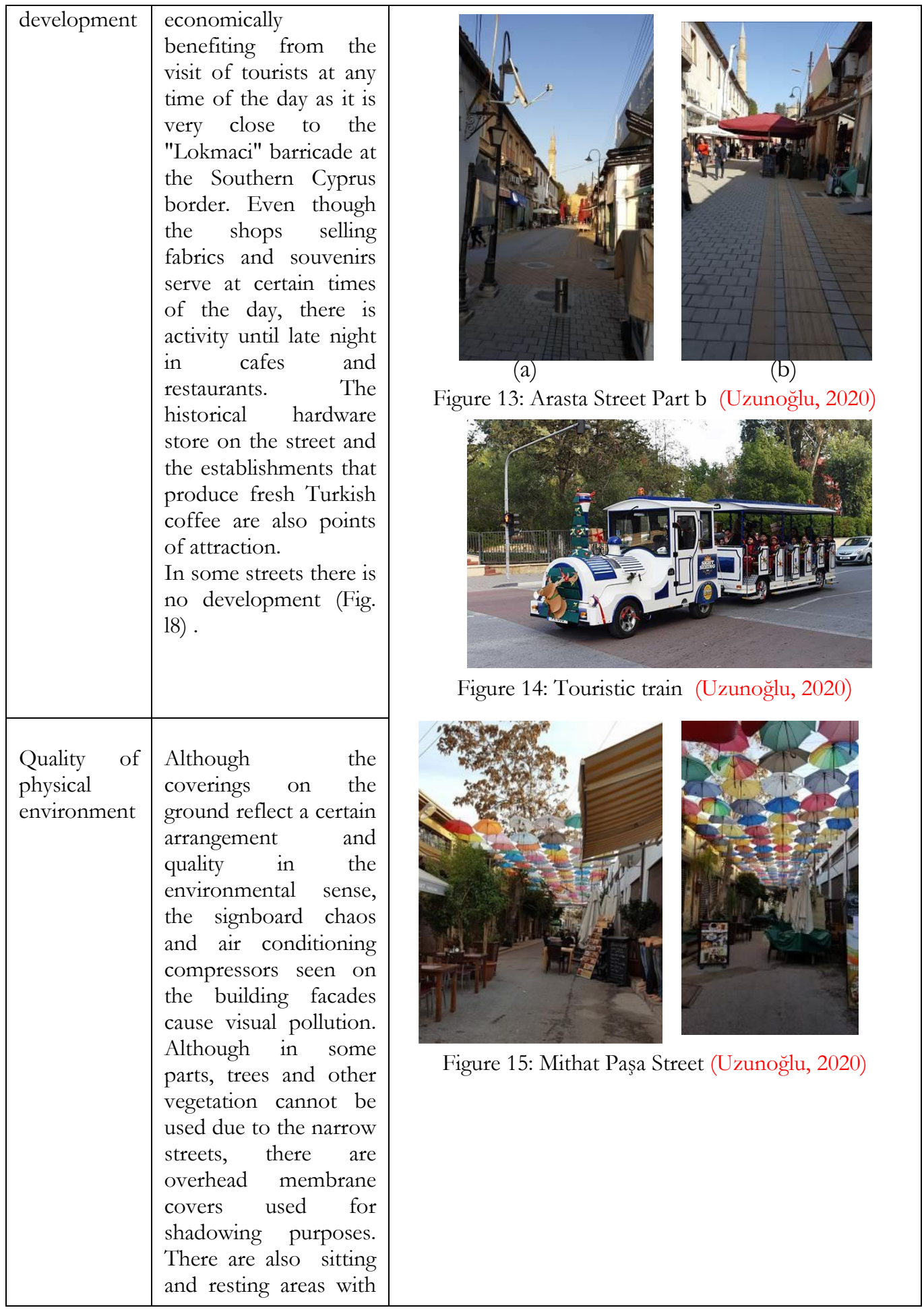




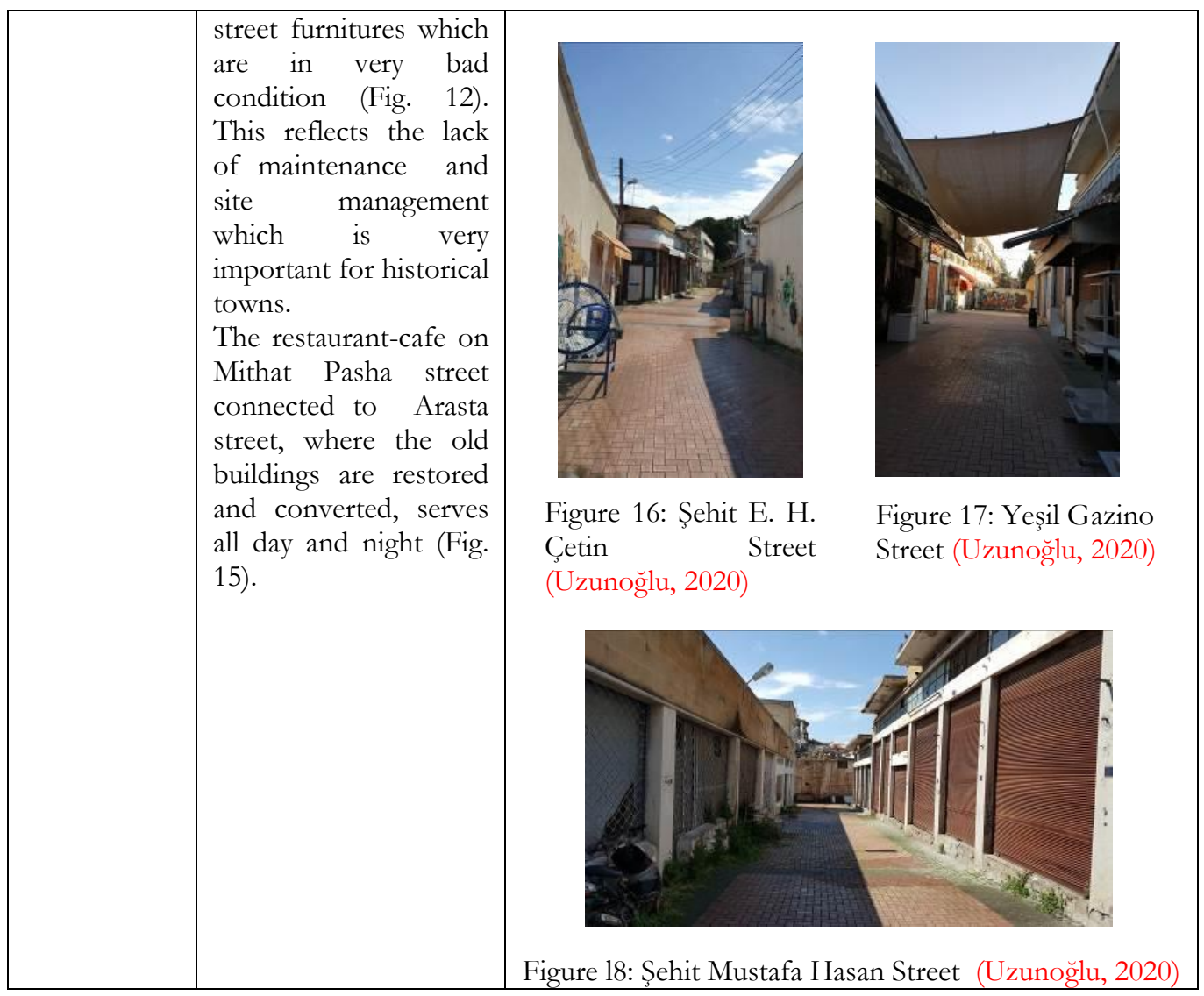

Table 5: Evkaf Square \& Evkaf Street

\begin{tabular}{|l|l|l|}
\hline Functions & $\begin{array}{l}\text { There are souvenir shops, } \\
\text { boutiques, cafes and restaurants } \\
\text { on the square }\end{array}$ \\
\hline Mobility & $\begin{array}{l}\text { At certain times, shops can get } \\
\text { services }\end{array}$ & $\begin{array}{l}\text { The street can be accessed via } \\
\text { car parks accessible by } \\
\text { individual vehicles. The road } \\
\text { located to the east of the area } \\
\text { and passing by the Great Inn } \\
\text { serves as a service road. }\end{array}$ \\
$\begin{array}{l}\text { Accessibility car } \\
\text { public } \\
\text { transportation }\end{array}$ & $\begin{array}{l}\text { Figure 19: Evkaf Square and street } \\
\text { map }\end{array}$ \\
\hline $\begin{array}{l}\text { Social/com } \\
\text { munity } \\
\text { activities. }\end{array}$ & $\begin{array}{l}\text { activities such as kermess and } \\
\text { concerts take place in the area. }\end{array}$ \\
\hline $\begin{array}{l}\text { Economic } \\
\text { development }\end{array}$ & $\begin{array}{l}\text { There are shops selling fabrics, } \\
\text { souvenirs, cafes and restaurants }\end{array}$
\end{tabular}




\begin{tabular}{|c|c|c|}
\hline & $\begin{array}{l}\text { in the area. Cafes and } \\
\text { restaurants are open until late } \\
\text { night and the visit of tourists } \\
\text { and local people contributes to } \\
\text { the area. }\end{array}$ & 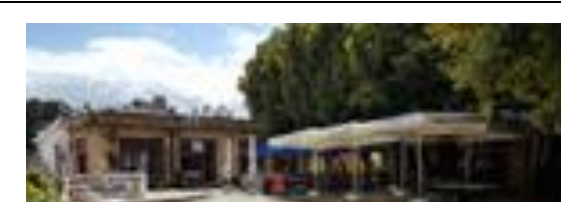 \\
\hline $\begin{array}{l}\text { Quality of } \\
\text { physical } \\
\text { environment }\end{array}$ & $\begin{array}{l}\text { The buildings around the } \\
\text { square need maintenance and } \\
\text { repair. Shaded areas for leisure } \\
\text { time have been created by } \\
\text { existing trees. }\end{array}$ & $\begin{array}{l}\text { Figure 20: Evkaf Square (Uzunoğlu, } \\
\text { 2020) }\end{array}$ \\
\hline
\end{tabular}


Table 6: Asmaalt1 Street \& Square

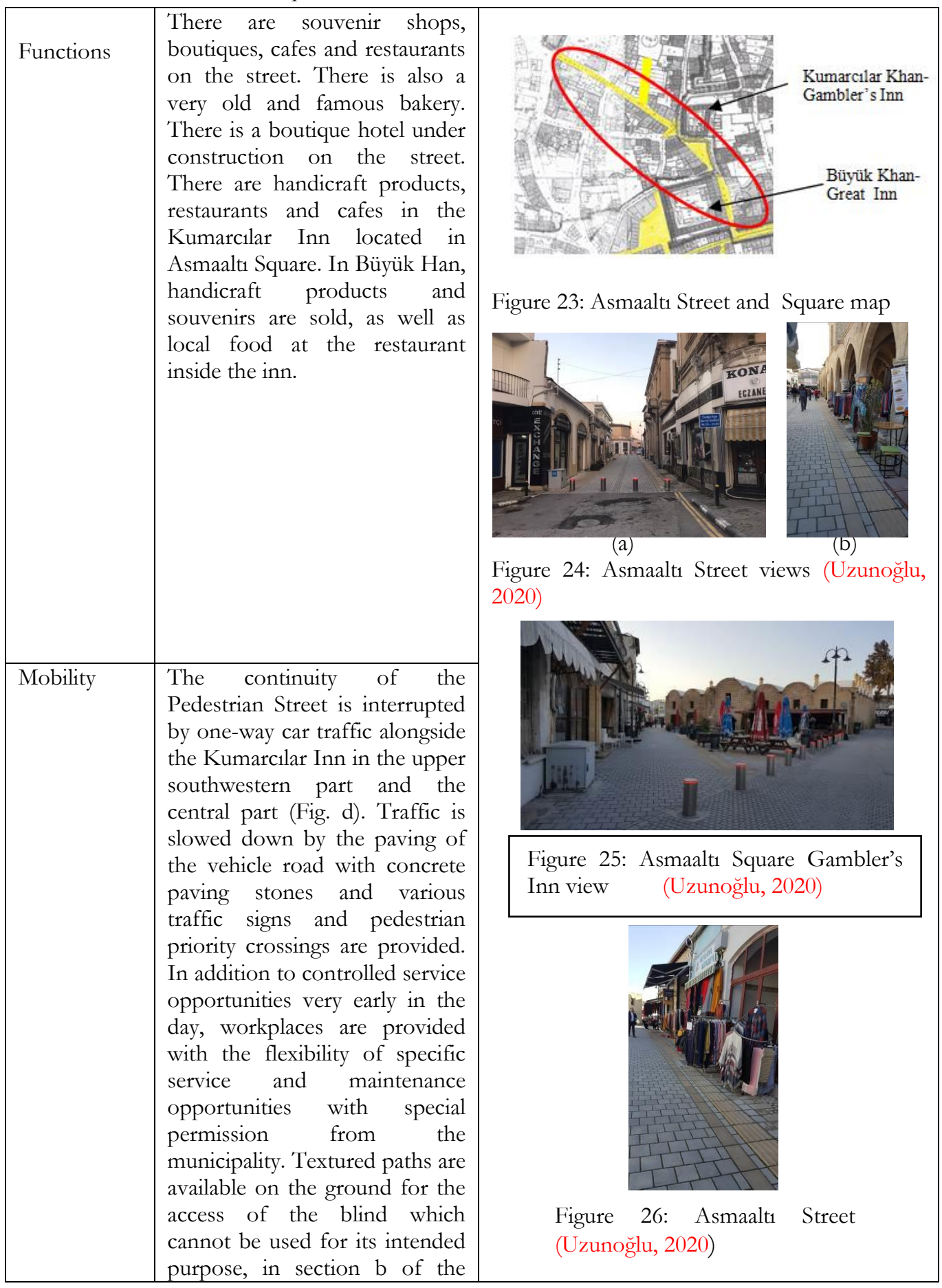




\begin{tabular}{|c|c|c|}
\hline & $\begin{array}{l}\text { street visible on the map. These } \\
\text { paths are blocked in some parts } \\
\text { of the streets (Fig.b, c). }\end{array}$ & \\
\hline $\begin{array}{l}\text { Accessibility } \\
\text { by car or } \\
\text { public } \\
\text { transportatio } \\
n\end{array}$ & $\begin{array}{l}\text { The street can be accessed via } \\
\text { car parks accessible by } \\
\text { individual vehicles (fig.4). At } \\
\text { the same time, a touristic train } \\
\text { for public transportation, } \\
\text { provides circulation } \\
\text { (sightseeing) by making loops in } \\
\text { certain routes in the Walled } \\
\text { City. }\end{array}$ & $\begin{array}{l}\text { Figure 27: Asmaaltı Square street } \\
\text { furnitures (Uzunoğlu, 2020) }\end{array}$ \\
\hline $\begin{array}{l}\text { Social/com } \\
\text { munity } \\
\text { activities. }\end{array}$ & $\begin{array}{l}\text { Social-cultural activities such as } \\
\text { entertainment events, kermes } \\
\text { and bicycle tours are also held } \\
\text { in Asmaaltı Street. In addition, } \\
\text { cultural activities such as } \\
\text { exhibitions and concerts also } \\
\text { take place in Büyük Han on the } \\
\text { street. }\end{array}$ & \\
\hline $\begin{array}{l}\text { Economic } \\
\text { development }\end{array}$ & $\begin{array}{l}\text { The Asmaalt1 area is very close } \\
\text { to the "Lokmac1" barricade on } \\
\text { the Southern Cyprus border. } \\
\text { For this reason, it provides } \\
\text { economic benefits at any time } \\
\text { of the day due to the visiting } \\
\text { tourists. Although boutiques } \\
\text { and souvenir shops on the } \\
\text { street serve at certain times of } \\
\text { the day, there are activities since } \\
\text { cafes and restaurants are open } \\
\text { until late at night. In addition to } \\
\text { the restaurants and cafes in } \\
\text { Büyük Han (Fig. 30) and } \\
\text { Kumarcilar Khan (Fig. 31), } \\
\text { souvenir and handicraft } \\
\text { producers also contribute to } \\
\text { economical development of the } \\
\text { region. }\end{array}$ & $\begin{array}{l}\text { Figure 29: Asmaaltı Square view } \\
\text { (Uzunoğlu, 2020) }\end{array}$ \\
\hline $\begin{array}{l}\text { Quality of } \\
\text { physical } \\
\text { environment }\end{array}$ & $\begin{array}{l}\text { Buildings along the street needs } \\
\text { renovation. Although the street } \\
\text { coverings reflect a certain order } \\
\text { and quality, it is observed that it } \\
\text { is not suitable for its purpose in } \\
\text { some places. Textured surfaces } \\
\text { made especially for the access } \\
\text { of visually impaired individuals } \\
\text { seem to be blocked and out of } \\
\text { use. }\end{array}$ & Figure 30: Büyük Khan-Great Inn (Uzunoğlu, \\
\hline
\end{tabular}




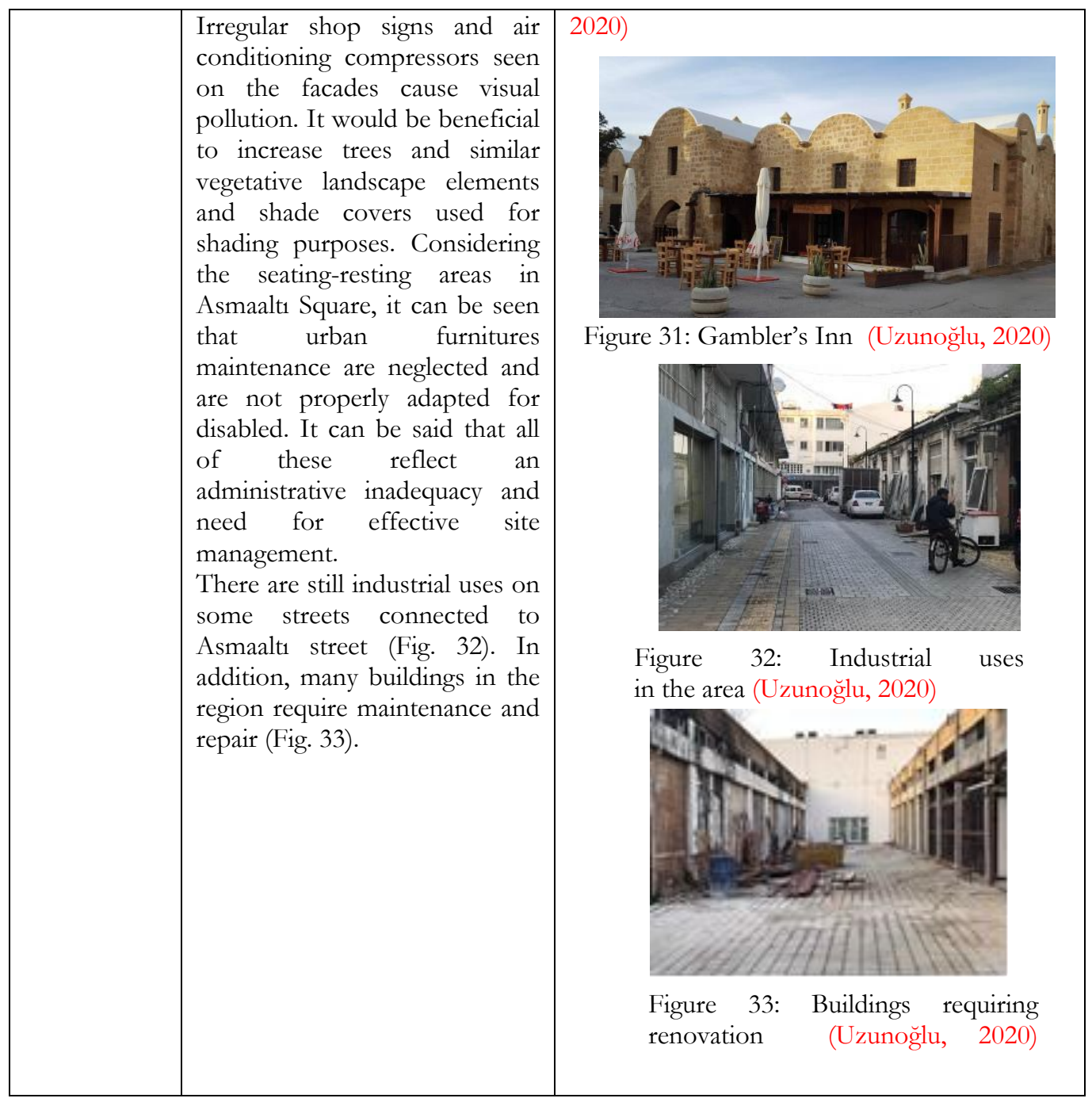

Table 7: Selimiye Square

\begin{tabular}{|l|l|l|}
\hline Functions & $\begin{array}{l}\text { In the area developed around } \\
\text { Selimiye Mosque, historically } \\
\text { known a Cathedral of Saint } \\
\text { Sophia, besides gift shops, } \\
\text { cafes and restaurants, there is } \\
\text { Yunus Emre Institute, } \\
\text { Lapidary Museum, The Union } \\
\text { of Cyprus Turkish } \\
\text { Municipalities building, Sultan } \\
\text { Mahmut II Library and a } \\
\text { handicraft center. }\end{array}$ \\
\hline Mobility & In addition to controlled & \\
\hline
\end{tabular}




\begin{tabular}{|c|c|c|}
\hline & $\begin{array}{l}\text { service opportunities very } \\
\text { early in the day, workplaces } \\
\text { are provided with the } \\
\text { flexibility of specific service } \\
\text { and maintenance } \\
\text { opportunities by special } \\
\text { permission from the } \\
\text { municipality. }\end{array}$ & $\mathrm{W}$ \\
\hline $\begin{array}{l}\text { Accessibility } \\
\text { by car or } \\
\text { public } \\
\text { transportation }\end{array}$ & $\begin{array}{l}\text { The street can be accessed via } \\
\text { car parks accessible by } \\
\text { individual vehicles (Fig.4). At } \\
\text { the same time, a touristic train } \\
\text { for public transportation, } \\
\text { provides circulation } \\
\text { sightseeing) by making loops } \\
\text { in certain routes in the Walled } \\
\text { City. }\end{array}$ & $\begin{array}{l}\text { Figure 35: Selimiye Street } \\
\text { (Uzunoğlu, 2020) }\end{array}$ \\
\hline $\begin{array}{l}\text { Social/commu } \\
\text { nity activities. }\end{array}$ & $\begin{array}{l}\text { Special day activities including } \\
\text { live music performances, } \\
\text { folklore and dance } \\
\text { performances are organized } \\
\text { around the Selimiye mosque. }\end{array}$ & $\begin{array}{l}\text { Figure 37: The } 1 \\
\text { the area (Uzui }\end{array}$ \\
\hline $\begin{array}{l}\text { Economic } \\
\text { development }\end{array}$ & $\begin{array}{l}\text { The Selimiye region is very } \\
\text { close to the "Lokmaci" } \\
\text { barricade on the Southern } \\
\text { Cyprus border. For this } \\
\text { reason, it provides economic } \\
\text { benefits at any time of the day } \\
\text { due to the visiting tourists. } \\
\text { Although boutiques and } \\
\text { souvenir shops on the street } \\
\text { serve at certain times of the } \\
\text { day, there is activity since } \\
\text { cafes and restaurants are open } \\
\text { until late at night. }\end{array}$ & $\begin{array}{lr} & \\
\text { Figure } & 41: \\
\text { Selimive } & \text { Street }\end{array}$ \\
\hline $\begin{array}{l}\text { Quality of } \\
\text { physical } \\
\text { environment }\end{array}$ & $\begin{array}{l}\text { Some of the buildings along } \\
\text { the street needs renovation. } \\
\text { The shading elements of some } \\
\text { shops on the street are } \\
\text { irregular and seem } \\
\text { incompatible to the } \\
\text { environment. During this } \\
\text { research, restoration works } \\
\text { had already started in the } \\
\text { Selimiye Mosque. }\end{array}$ & $\begin{array}{l}\text { Figure 42: Sultan Mahmut II } \\
\text { Library (Uzunoğlu, 2020) }\end{array}$ \\
\hline
\end{tabular}


Table 8: Siret Bahçeli Street-Ledra Street

\begin{tabular}{|c|c|c|}
\hline Functions & $\begin{array}{l}\text { There are souvenir shops, } \\
\text { boutiques, cafes and } \\
\text { restaurants on the way to } \\
\text { Lokmac1 gate. }\end{array}$ & (2) \\
\hline Mobility & $\begin{array}{l}\text { At certain times, shops on } \\
\text { the street can get services. }\end{array}$ & \\
\hline $\begin{array}{l}\text { Accessibility by } \\
\text { car or public } \\
\text { transportation }\end{array}$ & $\begin{array}{l}\text { The street can be accessed } \\
\text { from the car parks } \\
\text { accessible by individual } \\
\text { vehicles. }\end{array}$ & ifor. \\
\hline $\begin{array}{l}\text { Social/community } \\
\text { activities. }\end{array}$ & $\begin{array}{l}\text { Sometimes the political } \\
\text { demonstrations take place } \\
\text { at the Lokmaci border gate } \\
\text { by the activists. }\end{array}$ & $\begin{array}{l}\text { Figure 43: Street } \\
\text { map (Uzunoğlu, } \\
\text { 2020) }\end{array}$ \\
\hline $\begin{array}{l}\text { Economic } \\
\text { development }\end{array}$ & $\begin{array}{l}\text { There are boutiques and } \\
\text { souvenir shops on the } \\
\text { street. Cafes and } \\
\text { restaurants are open until } \\
\text { late at night. It is always a } \\
\text { busy and lively area } \\
\text { because it is on the } \\
\text { passageway to north and } \\
\text { south. }\end{array}$ & 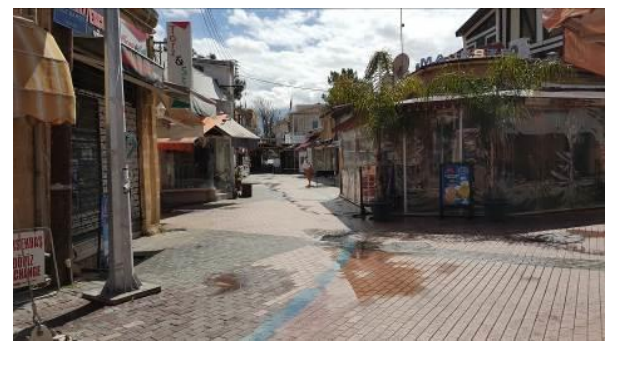 \\
\hline $\begin{array}{l}\text { Quality of physical } \\
\text { environment }\end{array}$ & $\begin{array}{l}\text { Buildings along the street } \\
\text { needs renovation. Irregular } \\
\text { shop signs seen on the } \\
\text { facades cause visual } \\
\text { pollution. It would be } \\
\text { beneficial to increase trees } \\
\text { and similar vegetative } \\
\text { landscape elements and } \\
\text { shading elements for } \\
\text { microclimatic comfort in } \\
\text { the street. }\end{array}$ & Figure 45: Street view (Uzunoğlu, 2020) \\
\hline
\end{tabular}


Table 9: Hasan Fahri Uzman Street

\begin{tabular}{|c|c|c|}
\hline Functions & $\begin{array}{l}\text { There are souvenir } \\
\text { shops, boutiques, } \\
\text { cafes and restaurants } \\
\text { on the street. }\end{array}$ & 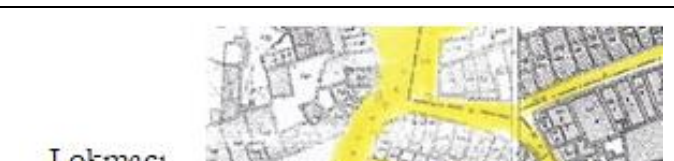 \\
\hline Mobility & $\begin{array}{l}\text { At certain times, } \\
\text { shops on the street } \\
\text { can get services. }\end{array}$ & \\
\hline $\begin{array}{l}\text { Accessibility by } \\
\text { car or public } \\
\text { transportation }\end{array}$ & $\begin{array}{l}\text { The street can be } \\
\text { accessed from the car } \\
\text { parks accessible by } \\
\text { individual vehicles. }\end{array}$ & istis \\
\hline $\begin{array}{l}\text { social/community } \\
\text { activities. }\end{array}$ & $\begin{array}{l}\text { There is no known } \\
\text { social and cultural } \\
\text { activity on the street. }\end{array}$ & Figure 45: Street map \\
\hline $\begin{array}{l}\text { Economic } \\
\text { development }\end{array}$ & $\begin{array}{l}\text { The street is } \\
\text { connected to Siret } \\
\text { Bahçeli Street-Ledra } \\
\text { Street on the } \\
\text { passageway to south } \\
\text { Nicosia. This creates } \\
\text { economic } \\
\text { contribution to the } \\
\text { area. }\end{array}$ & $\begin{array}{l}\text { (a) } \\
\text { Figure 45: Street views (Uzunoğlu, 2020) }\end{array}$ \\
\hline $\begin{array}{l}\text { Quality of } \\
\text { physical } \\
\text { environment }\end{array}$ & $\begin{array}{l}\text { Buildings along the } \\
\text { street needs } \\
\text { renovation. Shop } \\
\text { signs, showcases look } \\
\text { irregular and not } \\
\text { suitable for the } \\
\text { architectural character } \\
\text { of the environment }\end{array}$ & \\
\hline
\end{tabular}

Table 10: Sehit Cemal Mustafa Street

\begin{tabular}{|l|l|}
\hline Functions & $\begin{array}{l}\text { There are souvenir } \\
\text { shops, cafes and } \\
\text { restaurants on the } \\
\text { street. }\end{array}$ \\
\hline Mobility & $\begin{array}{l}\text { Shops, cafes and } \\
\text { restaurants on the } \\
\text { street can get services } \\
\text { at certain times. }\end{array}$ \\
\hline $\begin{array}{l}\text { Accessibility by by } \\
\text { car or public } \\
\text { transportation }\end{array}$ & $\begin{array}{l}\text { The street can be } \\
\text { through the parking }\end{array}$ \\
\hline
\end{tabular}




\begin{tabular}{|l|l|}
\hline & lots around. \\
\hline social/community & $\begin{array}{l}\text { There is no known } \\
\text { activities. }\end{array}$ \\
social and cultural \\
activity on the street. \\
Economic \\
development
\end{tabular} $\begin{aligned} & \text { The street is very } \\
& \text { close to the Siret } \\
& \text { Bahçeli Street-Ledra } \\
& \text { Street on the } \\
& \text { passageway to south } \\
& \text { Nicosia. This creates } \\
& \text { economic Street map } \\
& \text { contribution to the } \\
& \text { shops, cafe and } \\
& \text { restaurants on the } \\
& \text { street. Figure 47: Street views (Uzunoğlu, 2020) }\end{aligned}$

Table 11: Tüccarbaşı Street

\begin{tabular}{|l|l|}
\hline $\begin{array}{l}\text { Functional } \\
\text { objectives }\end{array}$ & $\begin{array}{l}\text { There are cafes and } \\
\text { restaurants on the } \\
\text { street. }\end{array}$ \\
\hline Mobility & $\begin{array}{l}\text { Cafes and } \\
\text { restaurants on the } \\
\text { street can get } \\
\text { services at certain } \\
\text { times. }\end{array}$ \\
\hline $\begin{array}{l}\text { Accessibility by bublic } \\
\text { car or pubeet can be } \\
\text { transportation }\end{array}$ & $\begin{array}{l}\text { The street by walking } \\
\text { through the parking } \\
\text { lots around. }\end{array}$ \\
\hline $\begin{array}{l}\text { Social/community } \\
\text { activities. }\end{array}$ & $\begin{array}{l}\text { There is no known } \\
\text { social and cultural } \\
\text { activity on the street. }\end{array}$ \\
\hline $\begin{array}{l}\text { Economic } \\
\text { development }\end{array}$ & $\begin{array}{l}\text { Sonnected to the } \\
\text { Siret Bahçeli Street- } \\
\text { Ledra Street on the } \\
\text { passageway to south } \\
\text { Nicosia. This creates } \\
\text { economic }\end{array}$ \\
\hline
\end{tabular}




\begin{tabular}{|l|l|l|}
\hline $\begin{array}{l}\text { Quality of physical } \\
\text { environment }\end{array}$ & $\begin{array}{l}\text { lontribution to the } \\
\text { shops, cafe and } \\
\text { restaurants on the } \\
\text { street. }\end{array}$ \\
$\begin{array}{l}\text { Buildings on the } \\
\text { street } \\
\text { renovation. need } \\
\text { outdoor seating } \\
\text { areas of cafes and } \\
\text { restaurants seem } \\
\text { quite irregular. Also, } \\
\text { electrical cables and } \\
\text { other installation } \\
\text { elements create } \\
\text { visual mess and they } \\
\text { don't look safe for } \\
\text { people using the } \\
\text { street. } \\
\text { Figure 49: Street views (Uzunoğlu, 2020) }\end{array}$ \\
\hline
\end{tabular}

Table 12: Baf Street

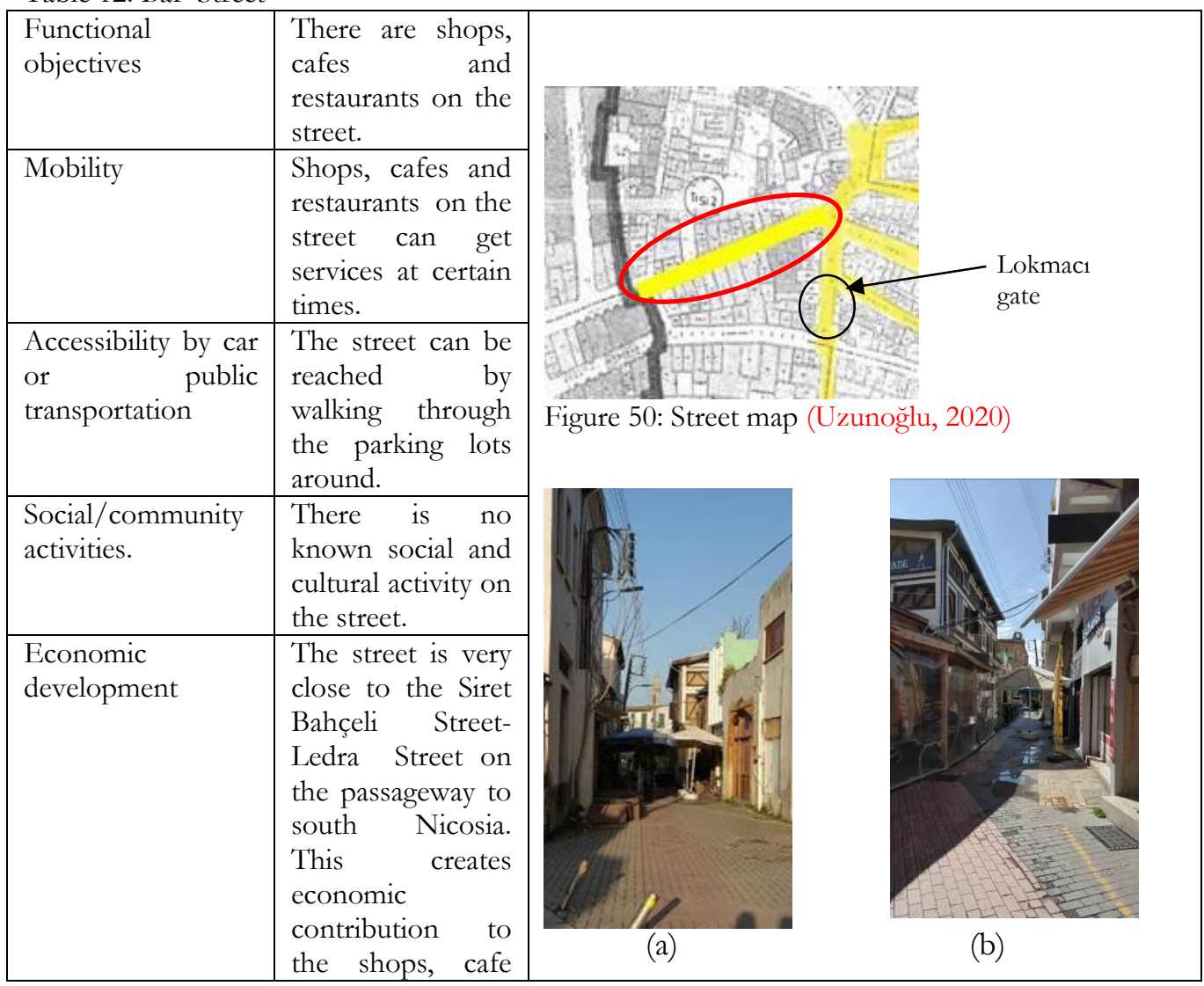




\begin{tabular}{|c|c|c|}
\hline & $\begin{array}{l}\text { and restaurants on } \\
\text { the street. }\end{array}$ & Figure 51: Street views (Uzunoğlu, 2020) \\
\hline $\begin{array}{l}\text { Quality of physical } \\
\text { environment }\end{array}$ & $\begin{array}{l}\text { Buildings on the } \\
\text { street need } \\
\text { renovation. The } \\
\text { arrangement of } \\
\text { outdoor seating } \\
\text { areas of cafes and } \\
\text { restaurants seem } \\
\text { quite irregular. } \\
\text { Also, electrical } \\
\text { cables and other } \\
\text { installation } \\
\text { elements create } \\
\text { mess and don't } \\
\text { look safe. }\end{array}$ & \\
\hline
\end{tabular}

\section{Results and Discussion}

It is a fact accepted by everyone that the importance of pedestrian areas for cities, especially for safe and comfortable movement of pedestrians. It is very important for pedestrians to be able to wander and shop without interfering with vehicular traffic, to meet their needs, to have a good time, to benefit from cafes and restaurants on the walking route. It is also known that such pedestrian streets are always a point of attraction. Especially in cities with historical characteristics and identity, pedestrian areas become more important. Perceiving the environment while walking, being able to breathe the historical atmosphere without worrying about traffic is a very important achievement for the locals as well as the tourists.

In this research, the existing situation of streets/areas that were pedestrianized in the Walled City were examined. The findings based on the research criteria (functions in the street, mobility, accessibility by car or public transportation, social/community activities, economic development and quality of physical environment) together with recommendations of the research are as follows:

The city of Nicosia is a whole surrounded by city walls. It is the last divided city in the world. Because of this division, some of the streets have lost their continuity because of the green line/buffer zone dividing the city into two. The integrity of the city is also effected and abandoned buildings along the border are left to deteriorate. In general, the 
streets should be restored to preserve the urban texture and identity. Existing buildings need to be restored and renewed in a way that they respond to contemporary living needs.

When considering the facades, it should be noted that AC compressors, which are already mounted on the facades, create visual pollution. Heating and cooling systems, which are essential because of the climate, must be solved without disturbing the facades and naturally the street view. In addition, it should be compulsory to bury the electrical cables which can be seen on the street facades and passing above the streets, in order not to spoil the texture. Shop signs should also be arranged in accordance with certain rules so as not to disturb the visual quality of the facades. It is seen that, urban furnitures available on the streets and squares examined are quite neglected. It is also observed that in some streets/squares they are not compatible with each other and the architectural environment as well. Increasing the landscape elements such as overhead shading elements and trees, which will be especially useful in the summer time, seems very necessary for the pedestrian's free movement and also for making them spend more time in the region.

Some of the recently pedestrianized streets have textured paths on the street surface for the access of visually impaired individuals. The outdoor seating areas reserved for cafes and restaurants in these streets and the stands used by the stores to display their products prevent the free movement of pedestrians, especially disableds having visual impairments. Textured surfaces made on the ground for the visually impaired in some streets are blocked in such a way that they prevent the free movement of these individuals safely and individually. In this sense, local government should take effective and deterrent measures.

It is seen as a good decision to allocate some buildings in the city to the departments related to architecture and art for vitalization of these pedestrianized areas. it is also clear that the pedestrianization projects in walled city and other arrangements to be made in this area, as being an open laboratory, will be very beneficial for students who study architecture and art.

\section{Conclusion}

In this study the pedestrianized streets/areas in the north Nicosia Walled City were examined. On-site observations have been done, the current status of the streets was evaluated in terms of the functions in the street, mobility, accessibility by car or public transportation, social/community activities, economic development, and quality of the physical environment. According to the results obtained, it can be concluded that radical decisions should be taken and implemented in terms of administrative and technical interests to ensure the sustainability of the city, improve the quality of life, to meet the needs of the region and local people in a modern sense and to provide the necessary infrastructure. At this point, legal arrangements should be made to increase the power and revenues of local governments and such projects should be enabled. To ensure the sustainability of the region in all respects, local governments should also create an active platform for exchange of views with business owners, other users, and residents in the region. 


\section{References}

Aydın. M. Ç., \& Ayataç, H. (2015). Pedesterianization case in the context of public interest: A pedesterianization project in Eminönü historical peninsula (Hobyar neighborhood and surroundings). ITU/AZ. 12(1). P. 3-13.

Brambilla, R., \& Longo, G. (2003). Pedestrain zones: a design guide. Time-Saver Standards for Urban Design. Mcgraw-Hill Pofessional. New York.

Chambers, s. (2017). The Oxford Street pedestrianisation is just the start of making London a place where more people walk. See also https://www.citymetric.com/transport/oxford-streetpedestrianisation-just-start-making-london-place-where-more-people-walk-3566

ElFouly, H. A. \& Gawad Ghaly, A. A. (2017). The perceived impact of pedestrianization on local businesses in Al-Muizz Egypt: A case study. International Journal of Development and Sustainability. 6 (7). p. 399411.ISSN: 2186-8662 - www.isdsnet.com/ijds

European Commission, (2004). Reclaiming City Streets for People: Chaos or Quality of Life? See also http://ec.europa.eu/environment/pubs/pdf/streets_people.pdf

Gladysz, M. (2018). Pedestrian friendly Montreal. See also https://heritagedowntowns.com/pedestrianfriendly-montreal/

Nieuwenhuijsen, M. J., \& Khreis, H. (2016). Car free cities: Pathway to healthy urban living. Environment International. Volume 94. p. 251-262.

de Souza, H. P., \& Mulaski, P. P. (2018). Curitiba Walk City: Revitalization of city center by making the city walking friendly, and sustainable. European Journal of Sustainable Developmen. 7(4), p.445450.

Zainol, R., Faizah, A., Aripin, M., Wafey, A.,Wang, C., Hafez, S.,Azlan Shah, A. (2016). Pedestrianization and walkability in a fast developing UNESCO world Heritage City. Open House International.41(1), p112-119.

Soni, N., \& Soni, N. (2016). Benefits of pedestrianization and warrants to pedestrianize an Area. Land Use Policy. Volume 57. p. 139-150.

UNDP, (2020). Emergency measures and upgrading of Ledra/Lokmac1. https://www.cy.undp.org/content/cyprus/en/home/operations/projects/partnershipforthefutur e/upgrading-of-local-and-urban-infrastructure---phase-ii/opening-of-ledra-lokmaci-crossing.html

Valente, M. (2014). How Buenos Aires Unclogged Its Most Iconic Street. See also https://www.citylab.com/transportation/2014/03/how-buenos-aires-unclogged-its-most-iconicstreet/8549/

Yassin, H. H. (2019). Livable city: An approach to pedestrianization through tactical urbanism. Alexandria Engineering Journal. 58(1). p. 251-259. 